\title{
Author Correction: Comparative osteoconductivity of bone void fillers with antibiotics in a critical size bone defect model
}

\author{
Rema A. Oliver ${ }^{1}$. Vedran Lovric ${ }^{1} \cdot$ Chris Christou $^{1} \cdot$ William R. Walsh $^{1}$
}

Published online: 6 October 2021

(c) The Author(s) 2021

Correction to: Journal of Materials Science: Materials in Medicine (2020) 31:80

https://doi.org/10.1007/s10856-020-06418-1.

In Section 2.2 Surgery; the 3rd sentence contains a minor typographical error. The sentence should read as follows: 'Following gaseous anaesthesia, $11 \times 20 \mathrm{~mm}$ defects were created into the cancellous bone of the distal femur and proximal tibia.'
Open Access This article is licensed under a Creative Commons Attribution 4.0 International License, which permits use, sharing, adaptation, distribution and reproduction in any medium or format, as long as you give appropriate credit to the original author(s) and the source, provide a link to the Creative Commons license, and indicate if changes were made. The images or other third party material in this article are included in the article's Creative Commons license, unless indicated otherwise in a credit line to the material. If material is not included in the article's Creative Commons license and your intended use is not permitted by statutory regulation or exceeds the permitted use, you will need to obtain permission directly from the copyright holder. To view a copy of this license, visit http://creativecommons. org/licenses/by/4.0/.
The original article can be found online at https://doi.org/10.1007/ s10856-020-06418-1.

\section{Rema A. Oliver}

rema.oliver@unsw.edu.au

1 Surgical and Orthopaedic Research Laboratories, UNSW Sydney, Prince of Wales Clinical School, Prince of Wales Hospital, Level 1 Clinical Sciences Building, Randwick, NSW, Australia 